\title{
Correction to: Enhanced differentiation of human pluripotent stem cells into pancreatic progenitors co-expressing PDX1 and NKX6.1
}

\author{
Bushra Memon ${ }^{1}$, Manale Karam², Sara Al-Khawaga ${ }^{1}$ and Essam M. Abdelalim*
}

\section{Correction}

The original article [1] contains a number of small errors which the authors would like to clarify:

1) In Fig. 1a of the original article, FGF10 concentration should be $50 \mathrm{ng} / \mathrm{ml}$ - as correctly stated in the Methods section - instead of $100 \mu \mathrm{g} / \mathrm{ml}$.

2) Also in Fig. 1a of the original article, Activin A and EGF concentrations should both be $100 \mathrm{ng} / \mathrm{ml}$ - as correctly stated in the Methods section - instead of $100 \mu \mathrm{g} / \mathrm{ml}$.

3) In the Methods section under the sub-heading "Differentiation of human pluripotent stem cells into pancreatic progenitor", the term, ' $50 \mathrm{ng} / \mathrm{ml}$
hFGF10' should be omitted from the following sentence:

"At the end of stage 3, media were changed to DMEM supplemented with $1 \% \mathrm{vol} / \mathrm{vol} \mathrm{B} 27,0.25 \mathrm{mM}$ vitamin C, $50 \mathrm{ng} / \mathrm{ml}$ hFGF10, $50 \mathrm{ng} / \mathrm{ml}$ hNOGGIN, $100 \mathrm{ng} / \mathrm{ml}$ $h E G F$, and $10 \mathrm{mM}$ nicotinamide (Sigma, USA) for

4 days of stage 4 treatment for each protocol (Fig. 1a)."

FGF10 was only added during stages $2 \& 3$ of differentiation as correctly depicted in Fig. 1a.

The corrected version of Fig. 1a can be viewed ahead.

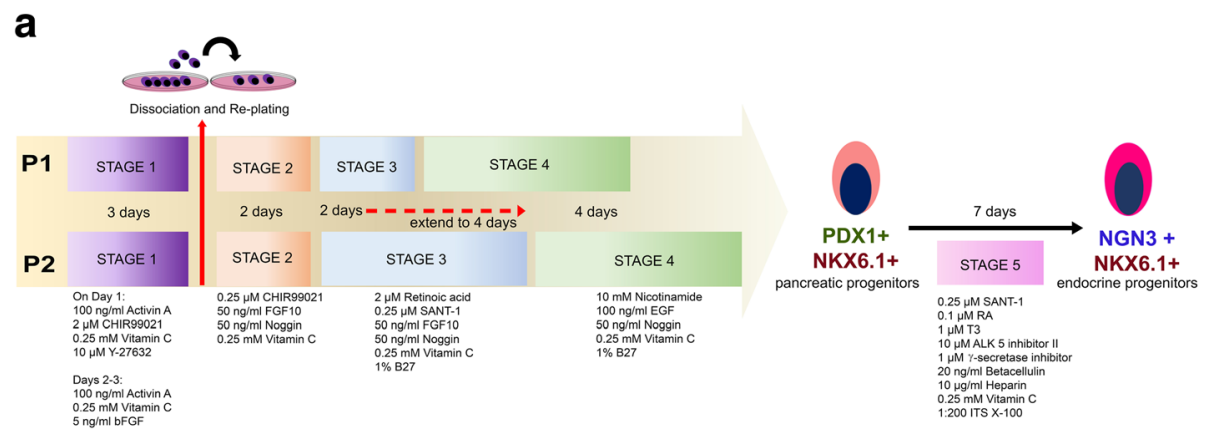

* Correspondence: emohamed@hbku.edu.qa

${ }^{1}$ Diabetes Research Center, Qatar Biomedical Research Institute, Hamad Bin

Khalifa University, Qatar Foundation, Doha, Qatar 


\section{Author details}

'Diabetes Research Center, Qatar Biomedical Research Institute, Hamad Bin

Khalifa University, Qatar Foundation, Doha, Qatar. ${ }^{2}$ Cancer Research Center,

Qatar Biomedical Research Institute, Hamad Bin Khalifa University, Qatar

Foundation, Doha, Qatar.

Received: 2 July 2018 Revised: 29 August 2018

Accepted: 29 August 2018 Published online: 07 October 2018

\section{Reference}

1. Memon B, et al. Enhanced differentiation of human pluripotent stem cells into pancreatic progenitors co-expressing PDX1 and NKX6.1. Stem Cell Res Ther. 2018;9:15. https://doi.org/10.1186/s13287-017-0759-z 